medRxiv preprint doi: https://doi.org/10.1101/2021.07.06.21260069; this version posted July 7, 2021. The copyright holder for this preprint (which was not certified by peer review) is the author/funder, who has granted medRxiv a license to display the preprint in perpetuity.

All rights reserved. No reuse allowed without permission.

Page 1 of 24

\title{
Title
}

\section{Prevalence and causes of vision impairment in Norwest Portugal: a capture and recapture study}

\section{Authors}

Pedro Lima Ramos $(1,2)$; pedro.limaramos@1nu.se

Rui Santana (3); ruisantana@ensp.unl.pt

Ana Patrícia Marques $(3,4)$; patricia.marques@1shtm.ac.uk

Inês Sousa (5); isousa@ math.uminho.pt

Amândio Rocha-Sousa (6); arsousa@med.up.pt

Antonio Filipe Macedo $(1,2)^{* *}$; antonio.macedo@ lnu.se

(1) Department of Medicine and Optometry Linnaeus University, Kalmar, Sweden;

(2) Low Vision and Visual Rehabilitation Lab, Department and Center of Physics Optometry and Vision Science, University of Minho, Braga, Portugal;

(3) Escola Nacional de Saúde Pública, Comprehensive Health Research Centre, NOVA University of Lisbon, Lisboa, Portugal;

(4) International Centre for Eye Health, London School of Hygiene \& Tropical Medicine, London, UK;

(5) Department of Mathematics and Applications and Center of Molecular and Environmental Biology, School of Sciences, University of Minho.

(6) Department of Surgery and Physiology, Faculty of Medicine, University of Porto, Porto, Portugal;

Name: Antonio Filipe Macedo

\section{** Corresponding author}

Address: Linnaeus University, Department of Medicine and Optometry, SE 39182, Kalmar, Sweden 


\title{
Abstract
}

\begin{abstract}
Aim
The aim of this study was to estimate the prevalence and causes of vision impairment (VI) in the Norwest of Portugal.
\end{abstract}

\section{Methods}

Information about people with VI was obtained from different sources in the Norwest of Portugal during a period spanning years 2014-2015. Log-linear models were applied to estimate the number of individuals missing from lists of cases obtained from Primary Care Centres, blind association (ACAPO) and from hospitals (the PCVIP-study). Log-linear models were used to estimate the crude prevalence and the category specific prevalence of VI. Causes of VI were obtained from the PCVIP-study.

\section{Results}

Crude prevalence of VI was $1.97 \%(95 \% \mathrm{CI}=1.56-2.54)$, and normalized prevalence was $1 \%$ $(95 \% \mathrm{CI}=0.78-1.27)$. The age-specific prevalence was $3.27 \%(95 \% \mathrm{CI},=2.36-4.90)$, older than 64 years, $0.64 \%(95 \% \mathrm{CI}=0.49-0.88)$, aged $25-64$ years, and $0.07 \%(95 \% \mathrm{CI}=0.045-0.13)$, aged less than 25 years. Prevalence amongst females was 1.3x higher than amongst males. The five leading causes of VI were Diabetic Retinopathy, Cataract, Age-related Macular Degeneration, Glaucoma and Disorders of the Globe.

\section{Conclusion}

The prevalence of VI in Portugal was within the expected range and in line with other European countries. A significant number of cases of VI might be due to preventable cases and, therefore, a reduction of the prevalence of VI in Portugal seems possible. Women and old people were more likely to have VI and, therefore, these groups require extra attention. Future studies are necessary to characterize temporal changes in prevalence of VI in Portugal.

\section{Keywords}

Prevalence, vision impairment, low vision, blindness, capture-recapture, cataract, diabetic retinopathy, age-related macular degeneration 
medRxiv preprint doi: https://doi.org/10.1101/2021.07.06.21260069; this version posted July 7, 2021. The copyright holder for this preprint

\section{Introduction}

2 Vision impairment (VI) leads to a significant loss of quality of life mostly due to

3 activity limitations, loss of independence and difficulties to find jobs [1-6]. Because VI leads

4 to a significant burden it is important to have regular vigilance (estimates) of cases of VI so

5 that the quality of eye care and events such as diseases that may be leading to more cases of

6 VI can be detected, evaluated, monitored and, eventually, vision loss can be prevented [7, 8].

7 One example of initiatives based on prevalence is VISION 2020 - an action of World Health

8 Organization and the International Agency for the Prevention of Blindness, aiming to prevent

9 and monitor VI and promote vision rehabilitation worldwide [9]. Recent estimates indicate

10 that VI remains a significant health problem in Europe; although, in some countries reliable

11 and updated information is lacking [9].

12 In 2020, in Western Europe, it has been estimated that there were 15400000 (95\%

13 CI, 13900 000-16 900 000) people with moderate or severe VI [9]. However, the prevalence

14 of VI and the methodology for the estimation varies significantly from country to country.

15 For example, a population-based study conducted in Denmark in 2016 defined VI as best

16 corrected visual acuity worse than 20/40 in the better-seeing eye. The study involved people

17 aged 20 to 94 years and found a prevalence of $0.4 \%$ (95\% CI, 0.2-0.7) [10]. A very different

18 estimation with significantly different values was performed France in 2005 [11], in this

19 study VI was self-reported and the prevalence was 1.95\%. In 2007 and for the population

20 aged 50 years or older, a study from Hungary reported a prevalence of $0.5 \%$ (95\% CI, $0.2-$

210.7 ) for severe VI and 5.1\% (95\% CI, 4.3-5.9) for moderate VI [12]. These numbers are

22 often hard to compare due to different age categories included and recruitment methods used;

23 although, they point to differences among European nations.

24 Differences in prevalence of VI in Europe, as summarized in Table 1, may be due to

25 not only study design but also, for example, due to differences in disease prevalence. VI and

26 blindness in Western Europe is mostly linked to age-related eye diseases, in Germany, for

27 example, that corresponds to $70 \%$ of all cases of blindness [13]. In Scotland, the leading

28 causes of VI are Age-related Macular Degeneration (AMD), Glaucoma, Diabetic Retinopathy

29 (DR), Myopic Degeneration, and Optic Atrophy [14]. Differences in disease prevalence and

30 disease severity are associated with factors such as prevention and access to treatments [8].

31 Inequalities in accessing treatments can be seen even within a single country such as Portugal

32 where unequal access to anti-VGEF injections was detected [15]. This makes it important to 
medRxiv preprint doi: https://doi.org/10.1101/2021.07.06.21260069; this version posted July 7, 2021. The copyright holder for this preprint (which was not certified by peer review) is the author/funder, who has granted medRxiv a license to display the preprint in perpetuity.

All rights reserved. No reuse allowed without permission.

33 investigate prevalence and causes of VI as detailed as possible at national and regional levels.

34 One method to study prevalence when cross-sectional studies of the population are

35 unavailable is called capture-recapture (CR).

36 CR methods have been used to estimate the prevalence of several eye conditions [16-

37 24]. CR methods is a methodology that can overcome the problem of cases that are never

38 captured by, for example, registers for the visual impaired [25-27]. For a detailed description

39 on how to use CR methods we recommend reading our review about the method [28]. Due

40 the lack of information about the prevalence of VI in Portugal, we conducted a study with CR

41 methods using data from different sources. The aim of this study was to estimate the

42 prevalence and the main causes of VI in Portugal using CR methods.

\section{$==$ Table 1: Prevalence of vision impairment in European countries ==}

\section{Methods}

Information about people with VI was obtained from different sources in the Norwest

3 of Portugal during a period spanning years 2014-2015. The geographical coverage included

442 municipalities from two provinces: Minho, population density $=241.1$ inhabitants $/ \mathrm{km}^{2}$

5 and Douro Litoral, population density $=742.4$ inhabitants $/ \mathrm{km}^{2}$, national CENSUS 2011 [29].

6 The study was conducted in accordance with the tenets of the Declaration of Helsinki,

7 approved by the local ethics committees of the participating hospitals and by the ethical

8 committee for Life Sciences and Health of the University of Minho, Ref. SECVS-084/2013;

9 data protection process numbers 9936/2013 and 9793/ 2017.

10 Possible sources of patients with visual acuity in the better eye of 0.5 decimal

11 (0.30logMAR) or worse and/or visual field less than 20 degrees were investigated [30]. The

12 first source were Primary Care Centres that were used for list L1. This list contained subjects

13 that applied, for example, for medical certificates of VI. According to the Portuguese law

14 people with a level of impairment of $60 \%$ or more are entitled to, amongst other, tax

15 exemption, completely free health care or early retirement [31]. As an example, to get a

16 degree of $60 \%$ or more from vision only, one eye must have no measurable acuity and the

17 other can have acuity up 0.2 decimal [32] Although, for this certificate all types of

18 impairments can be combined, e.g. vision and motor impairments, to reach the final score.

19 Because of that, cases mapped as having VI were analysed and only those with field or acuity 
medRxiv preprint doi: https://doi.org/10.1101/2021.07.06.21260069; this version posted July 7, 2021. The copyright holder for this preprint

matching the inclusion criteria were included in this study. The second source used was an association for the visually impaired named ACAPO and their records were used in the second list L2. To be member of ACAPOI people must be visually impaired (low vision or blind).

The third list L3 was obtained from the PCVIP-study, a hospital-based study whose aim was to determine prevalence, causes and costs of VI in Portugal [33-35].The study gathered demographic, clinical, and socioeconomic information of people with VI. Participants were selected among patients attending ophthalmologists' appointments at four Portuguese public hospitals: Hospital de Braga, Hospital Senhora da Oliveira-Guimarães, Hospital de Santa Maria Maior-Barcelos and Centro Hospitalar e Universitário de São João Porto. The initial database included people with acuity 0.5 decimal (0.30logMAR) or worse, to make compatible with the definition of VI in the ICD9 [30] and with the acuity in the other lists only cases with visual acuity below 0.3 decimal in the better-seeing eye were used for the estimation of prevalence.

All lists had variables that allowed assessment of repeated cases by using a string or combination of strings that form identifiers or "tags". Information available included: initials, date of birth, sex and municipality. The list from the hospitals also included information about the cause of VI. An example of a tag could be JS130519802 where JS are the initials (first and last name), 13051980 is the date of birth (13-05-1980) and the last digit (2) defines sex -2 is a female in the example given. By matching the identity strings (tags) of the three lists, it was possible to ascertain the number of individuals present in all three lists and the number of individuals present at any combination of two lists.

To be used in CR lists need to be obtained at approximately the same time, or based on different sources that represent approximately the same population [36]. In addition, to obtain reliable results with CR certain assumptions need to be meet: 1) the sources of lists are independent - this implies that the probability of a subject being in both list A and list B equals the product between the probability of being in A alone and the probability of being in B alone [37], 2) the probability of association within each source (catchability) is equal for all individuals - the probability may vary from one list to another, or be constant overall [37, 38], 3 ) the population is closed (no births, deaths or migrants). These assumptions are restrictive and, when applied to medical conditions, are unlikely to be strictly followed. Log-linear models are one way of handling, for example, lists that are not completely independent [37].

Log-linear models were applied to estimate the number of individuals missing from all three lists [38]. Log-linear models result from the application of Poisson regression 
medRxiv preprint doi: https://doi.org/10.1101/2021.07.06.21260069; this version posted July 7, 2021. The copyright holder for this preprint (which was not certified by peer review) is the author/funder, who has granted medRxiv a license to display the preprint in perpetuity.

All rights reserved. No reuse allowed without permission.

54 models to Table 2, the table summarizes all possible capture history for any case listed. The

55 capture history is illustrated in Figure 1. The logarithm of the count in each cell of the table is

56 modelled as a linear function with terms indicating the presence or absence in the lists and

57 terms modelling possible pairwise dependences between lists. After choosing the best

58 possible model we obtained an estimate of the dimension of the hidden population and

59 consequently an estimate of the number of individuals with VI. The same procedure was used

60 to compute category specific prevalence according to age and sex. Within each category

61 several models were applied to sub-lists obtained from the main lists.

62

\section{Results}

The total number of inhabitants in the geographical area covered by the current study

3 was 3010 964. The list from Primary Care Centres (L1) had 208 cases (52\% females) with a

4 mean age of 60 years ( $\mathrm{SD}=18.93)$. The list with the cases from ACAPO (L2) had 878 cases

5 (43\% females) with a mean age of 54 years ( $\mathrm{SD}=18.0)$. The list from the Hospitals (L3) had

64272 cases ( $58 \%$ females) with a mean age of 74 years $(\mathrm{SD}=18.0)$. The Venn diagram in

7 Figure 1 shows the intersection between lists obtained from comparisons between identity

8 strings. Figure 1 shows that, for example, 39 individuals were in L3 and L1 and were not in

9 L2; 13 individuals were in all three lists; 4161 individuals were only in L3. Table 2 provides

10 the possible capture histories and the number of individuals with that history. For example, a

11 subject has a capture history ( 1100$)$ when she or he was in L1 and L2 but not in L3.

$==$ Figure 1: Venn diagram representing the intersection between the three lists == $==$ Table 2: Number of individuals presenting each possible capture history ==

Log-linear models admitting possible list dependence scenarios were applied to model the counts in Table 2. The model is expected to estimate the value of $x$ (see also Table 2) that corresponds the number of individuals with capture history $\left(\begin{array}{lll}0 & 0 & 0\end{array}\right)$. That is, the size of the hidden population or the number of individuals not captured by any of the three lists. The estimate of total number of people with VI $(\mathrm{N})$ was given by the expression: $\mathrm{N}=$ $x+13+38+39+59+118+768+4162$, the value of $\mathrm{N}$ changes from model to model because the estimates obtained to the unknown $x$ value. All possible list dependence scenarios were 
medRxiv preprint doi: https://doi.org/10.1101/2021.07.06.21260069; this version posted July 7, 2021. The copyright holder for this preprint (which was not certified by peer review) is the author/funder, who has granted medRxiv a license to display the preprint in perpetuity.

All rights reserved. No reuse allowed without permission.

24 considered resulting in seven models summarized in Table 3. Code used to implement these models in R Statistics ( v3.6.1), package Rcapture [39, 40] is provided in Appendix A.

\section{== Table 3: All possible log-linear models and resulting prevalence estimates ==}

The list dependence scenario L1L2 and L1L3 generated a model fitting the data well, goodness of fit test $p=\operatorname{Pr}\left(\chi_{1}^{2} \geq 0.009\right)=0.92$. It is also the model with the lower value of

AIC. According to the model the crude prevalence of VI as estimated in this study was $1.97 \%$

(95\% CI, 1.56-2.54). The normalized prevalence was 1\% (95\% CI, 0.78-1.27).

Completeness, that is, the proportion of the population with VI that has been captured

by our three lists, assuming that the size $\mathrm{N}$ of the population with VI was 59316 , was $9 \%$.

33 Completeness was computed using the formula below, in the formula, $n_{100}$ is the number of cases with capture history $\left(\begin{array}{lll}1 & 0 & 0\end{array}\right)$ and the meaning is the same for all other parcels such as $n_{010}$ in the denominator of the fraction.

$$
\begin{gathered}
\frac{n_{100}+n_{010}+n_{001}+n_{111}+n_{101}+n_{011}+n_{110}}{\widehat{N}} \times 100 \\
=\frac{118+768+4161+13+39+59+38}{59316} \times 100 \approx 9 \% .
\end{gathered}
$$

Table 4 shows category specific prevalence according to age and Table 5 category specific prevalence according to sex. To run new log-liner models for each category we divided the initial lists according to the desired categories. Subsamples for each category were used to generating new Venn diagrams. Log-linear models for each subsample were set as given in Table 3, that means seven different dependency scenarios for each, for example, age category. The best model was chosen using criteria of AIC and p-values.

\section{$==$ Table 4: Age-specific prevalence $==$}

\section{$==$ Table 5: Sex-specific prevalence $==$}

Figure 2 illustrates the distribution of causes of VI. This information was available from L3 (from the hospitals), causes were classified according to the ICD9. DR was the most common cause of VI with $31 \%$ (95\% CI, 29 - 32) of the cases in L3, followed by Cataract 15\% (95\% CI, 14 - 17), AMD 14\% (95\% CI, 13 - 15), Glaucoma 10\% (95\% CI, 9 - 11) and

51 Disorders of the globe (DG) 5\% (95\% CI, 4 - 6). Figure 2 also shows the causes per age

52 group and confidence interval for each cause are given in the figure legend. 
medRxiv preprint doi: https://doi.org/10.1101/2021.07.06.21260069; this version posted July 7, 2021. The copyright holder for this preprint (which was not certified by peer review) is the author/funder, who has granted medRxiv a license to display the preprint in perpetuity.

All rights reserved. No reuse allowed without permission.

Page 8 of 24

53

54

\section{Discussion} detected at hospitals.

\section{$==$ Figure 2: Distribution of causes of visual impairment $==$}

The current study investigated the prevalence and causes of VI in the Norwest of Portugal. Crude estimates of prevalence point that 2 out of 100 inhabitants of the Portuguese north-western population suffer from VI. Category-specific prevalence by age and by sex revealed higher prevalence among older people and among women. The top causes of VI included DR and Cataract, information about causes of VI was available only from cases

Prevalence of VI for the general population was within the expected values. Our results are in line with those reported in neighbour countries such as Spain [41]. This was an expected result because both countries have similar populations. Our results were also in line with a French study reporting a prevalence of VI of 1.95\% [11]. A study from Iceland reported a prevalence of $0.96 \%(95 \% \mathrm{CI}, 0.37-1.55)$ [1] that is similar to our study if we consider the normalized prevalence instead of the crude prevalence. Another study conducted in 2000 in Copenhagen, urban Denmark, also found a value for prevalence close to 1\% [42]. In contrast, a study from 2016 in rural Denmark found a prevalence of $0.4 \%$ (95\% CI, $0.2-$ 0.7) [10] which is similar to what has been reported in Germany $0.37 \%$ (95\% CI, 0.28-0.49) [7]. Recent studies show that the incidence of VI in countries like Germany has been reducing and, therefore, more recent studies are likely to report lower prevalence of VI than older studies [43]. One possible explanation for slightly higher values of prevalence of VI in our study in Portugal can be the prevalence and incidence of, for example, diabetes and DR $[44,45]$. In other words, some European countries seem better at preventing vision loss from common eye diseases such has DR and removing it from top cause of VI, while in Portugal at the time of our study DR was still the top cause of VI [46]. In other parts of Europe such as Hungary prevalence of VI was higher than our study, here VI is expected affect more than $5 \%$ of the population [12]. In short, prevalence of VI in Portugal was similar to neighbour countries, but slightly higher than in countries with, possibly, better preventive mechanisms of vision loss. Our results point that is possible to reduce the prevalence of VI in Portugal, the exact strategies can be inspired from European countries reporting lower prevalence of VI.

VI was more common among elderly people, it increased from about 7 out of 10,000 in the population under 25 years to 60 out of 10,000 in the age range 25-64 years and about 
medRxiv preprint doi: https://doi.org/10.1101/2021.07.06.21260069; this version posted July 7, 2021. The copyright holder for this preprint

(which was not certified by peer review) is the author/funder, who has granted medRxiv a license to display the preprint in perpetuity.

All rights reserved. No reuse allowed without permission.

Page 9 of 24

31300 out of 10,000 in the population with 64 or more years, these findings are in line with

32 other studies [7]. A study in Denmark found that VI was 9x more prevalent amongst people

33 with more than 64 years than amongst people in the age range 20-64 years [42]. Our results

34 for the older population are also in line with the estimates from a recent meta-analysis

35 estimating the prevalence of VI in people 55 years or older in European countries. The study

36 that included data from Portugal, estimated an overall prevalence of VI for those above 55

37 years close to $2.75 \%$ [47, 48]. For age under 25 years, prevalence of VI in our study was low

38 and in line with several other studies [49-51]. For example, our results were similar to data

39 available from Sweden, in 1997 the age-specific prevalence of VI as 10.9/10,000 amongst

40 people under the age of 19 years [51]. A more recent study from China that investigated VI

41 amongst pre-school children also found a similar prevalence [52]. There was a good

42 agreement between our results and similar studies, small differences might be due, among

43 other factors, to temporal changes in prevalence of VI and the age-range criteria.

44 Prevalence of VI among females was $1.3 \mathrm{x}$ higher than the prevalence among males,

45 this result is in line with the trend reported in a recent meta-analysis covering European

46 countries [47]. These results are also consistent with studies from Germany [7], VI among

47 females was 1.4x higher than among males, and from Spain [41], prevalence amongst

48 females was $1.7 x$ higher than amongst males. The female-to-male ratio is expected to vary

49 from 1.1 is Sub-Saharan Africa to 1.25 in Europe [53]. Causes for this female-to-male ratio

50 above 1 are likely to include factors such as gender inequalities in access to health care [54].

51 The top two causes of VI in our study were DR and Cataract. Information about

52 causes of VI in our study was available from hospitals and that might increase the frequency

53 of cases with treatable diseases such as the top two causes. The main causes of VI in Europe

54 are diverse [55] and we provide a summary of some studies in Table 6 [7, 14, 42, 56, 57].

55 Studies compiled in Table 6 show that, for example, DR was the top cause of VI only in our

56 study. We can speculate that the main reason was that when our study was conducted the

57 preventive effects of DR screening were not yet visible in Portugal and, therefore, the number

58 of cases of VI caused by DR was high [44]. This contrasts with other countries such as

59 Germany or Denmark where DR appears down in the list of main causes of VI. Probably

60 preventive DR measures were implemented earlier than in Portugal [44]. While in some

61 studies DR remains in second place as cause of VI [58] it seem that the trend is to go further

62 down in the list $[59,60]$. Our second cause of VI, Cataract, has also been reported as

63 important cause of VI in Denmark, Canada and the UK [10, 61, 62]. We believe that, for

64 example, in Denmark, the high number of cases of Cataract causing VI was due to the 
medRxiv preprint doi: https://doi.org/10.1101/2021.07.06.21260069; this version posted July 7, 2021. The copyright holder for this preprint (which was not certified by peer review) is the author/funder, who has granted medRxiv a license to display the preprint in perpetuity.

All rights reserved. No reuse allowed without permission.

65 inclusion criteria with acuity 20/40. In many countries this is also the criteria to undergo

66 cataract surgery. In our study we believe that a considerable percentage of cases of VI caused

67 by Cataract was due to long queues for surgery at the time of our study [63].

==Table 6: Causes of visual impairment in 6 European countries, including Portugal ==

In this study we used capture-recapture models to investigate prevalence of VI. Some models showed high quality of fit which gives credibility to the prevalence values that we obtained. The best models were the ones with the list dependences Primary Care Centres/Hospitals and Primary Care Centres/Blind Association, it is important to recapitulate that CR methods give the estimates for the non-captured cases or hidden population unavailable from our data sources. The Primary Care Centres/Hospitals dependence is understandable because medical certificates of VI require a report from an ophthalmologist that, most likely, is the assistant physician at the hospital. The Primary Care Centers/Blind Association dependence is explained by the fact that the Blind Association recommends their members to get a medical certificate of VI. The fact that completeness was about $9 \%$ is a

81 limitation of our study, to solve this we needed more information from Primary Care Centres.

82 This limitation may be addressed in future studies with better standardized digital records that allow more efficient anonymous data sharing.

In conclusion, the results of the current study showed that prevalence of VI in

85 Portugal was within the expected range and in line with other neighbour countries. A

86 significant number of cases of VI detected was due to preventable causes, in other words, a

87 reduction of cases of VI in Portugal is possible with improved access to eye care and

88 effective diseases monitorization. In addition, basic and comprehensive vision rehabilitation

89 is necessary to support people with VI [64]. Future studies are necessary to characterize

90 temporal changes and the efficacy of public health measures such as DR screening at

91 reducing prevalence of VI.

\section{Funding}

93 This study was supported by FCT (COMPETE/QREN) grant reference PTDC/DPT-

94 EPI/0412/2012 in the context of the Prevalence and Costs of Visual Impairment in Portugal:

95 a hospital-based study (PCVIP-study). PLR is funded by FCT (COMPETE/QREN) grant 
medRxiv preprint doi: https://doi.org/10.1101/2021.07.06.21260069; this version posted July 7, 2021. The copyright holder for this preprint (which was not certified by peer review) is the author/funder, who has granted medRxiv a license to display the preprint in perpetuity.

All rights reserved. No reuse allowed without permission.

Page 11 of 24

96 reference SFRH/BD/119420/2016. AFM if founded by the faculty of Health and Life

97 Sciences at Linnaeus University.

\section{Acknowledgments}

99 Authors report on behalf of the Portuguese visual impairment study group (PORVIS-group):

100 António Filipe Macedo, PhD, Principal Investigator; Department of Medicine and Optometry

101 Linnaeus University Kalmar, Sweden and Vision Rehabilitation Lab Centre/Department of

102 Physics and Optometry University of Minho Braga, Portugal.Amandio Rocha-Sousa, MD,

103 PhD, FEBO; Marta Silva, MD Ophthalmologist; Sara Perestrelo, MD Ophthalmologist; João

104 Tavares-Ferreira, MD Ophthalmologist; Ana Marta Oliveira, research coordinator;

105 Department of Surgery and Physiology, Faculty of Medicine University of Porto and/or

106 Ophthalmology Department: Centro Hospitalar e Universitário de São João. Cristina Freitas,

107 MD Ophthalmologist; Keissy Sousa, MD Ophthalmologist; Ricardo Leite, MD

108 Ophthalmologist; José Carlos Mendes, MD Ophthalmologist; Andreia Braga Soares, MD

109 Ophthalmologist; Rui Carneiro Freitas, MD Ophthalmologist; Department of

110 Ophthalmology, Hospital de Braga. Pedro Reimão, MD Ophthalmologist; Marco Vieira, MD

111 Ophthalmologist; Joel Monteiro, MD Cardiologist; Department of Ophthalmology, Centro

112 Hospitalar de Alto Ave, Guimarães. Natacha Moreno, MD, Ophthalmologist; Department of

113 Ophthalmology, Hospital Sta Maria Maior, Barcelos. Gary Rubin, $\mathrm{PhD}$ (project adviser);

114 UCL-Institute of Ophthalmology, London, UK. Ana Patricia Marques, PhD; Rui Santana,

115 PhD; Principal Investigator; National School of Public Health, NOVA University of Lisbon,

116 Portugal. Laura Hernandez-Moreno, PhD candidate; Pedro Lima, PhD candidate; Low Vision

117 and Visual Rehabilitation Lab, Department and Center of Physics - Optometry and Vision

118 Science, University of Minho, Braga, Portugal.

119 
medRxiv preprint doi: https://doi.org/10.1101/2021.07.06.21260069; this version posted July 7, 2021. The copyright holder for this preprint (which was not certified by peer review) is the author/funder, who has granted medRxiv a license to display the preprint in perpetuity.

\section{References}

1. Gunnlaugsdottir, E., A. Arnarsson, and F. Jonasson, Prevalence and causes of visual impairment and blindness in Icelanders aged 50 years and older: the Reykjavik Eye Study. Acta Ophthalmol, 2008. 86(7): p. 778-85.

2. $\quad$ West, S.K., et al., How does visual impairment affect performance on tasks of everyday life? The SEE Project. Salisbury Eye Evaluation. Arch Ophthalmol, 2002. 120(6): p. 774-80.

3. Macedo, A.F., et al., Visual and health outcomes, measured with the activity inventory and the EQ-5D, in visual impairment. Acta Ophthalmol, 2017. 95(8): p. e783-e791.

4. Hernández-Moreno, L., et al., Is perceived social support more important than visual acuity for clinical depression and anxiety in patients with age-related macular degeneration and diabetic retinopathy? Clin Rehabil, 2021: p. 269215521997991.

5. Marques, A.P., et al., Productivity Losses and Their Explanatory Factors Amongst People with Impaired Vision. Ophthalmic Epidemiol, 2019. 26(6): p. 378-392.

6. $\quad$ Marques, A.P., et al., The use of informal care by people with vision impairment. PLoS One, 2018. 13(6): p. e0198631.

7. Wolfram, C., et al., The Prevalence of Visual Impairment in the Adult Population. Dtsch Arztebl International, 2019. 116(17): p. 289-95.

8. Welp, A., R. Woodbury, and M. McCoy. Making Eye Health a Population Health Imperative: Vision for Tomorrow. National Academies of Sciences, Engineering, and Medicine; Health and Medicine Division; Board on Population Health and Public Health Practice; Committee on Public Health Approaches to Reduce Vision Impairment and Promote Eye Health 2016.

9. Bourne, R.R.A., et al., Magnitude, temporal trends, and projections of the global prevalence of blindness and distance and near vision impairment: a systematic review and meta-analysis. Lancet Glob Health, 2017. 5(9): p. e888-e897.

10. Høeg, T.B., et al., Danish Rural Eye Study: Epidemiology of Adult Visual Impairment. Ophthalmic Epidemiol, 2016. 23(1): p. 53-62.

11. Brézin, A.P., et al., Prevalence and burden of self-reported blindness, low vision, and visual impairment in the French community: a nationwide survey. Arch Ophthalmol, 2005. 123(8): p. 1117-24.

12. Szabó, D., et al., Visual impairment and blindness in Hungary. Acta Ophthalmologica, 2018. 96(2): p. 168-173.

13. Finger, R.P., et al., Blindness and visual impairment in Germany: a slight fall in prevalence. Deutsches Arzteblatt international, 2012. 109(27-28): p. 484-489.

14. Bamashmus, M.A., B. Matlhaga, and G.N. Dutton, Causes of blindness and visual impairment in the West of Scotland. Eye (Lond), 2004. 18(3): p. 257-61.

15. Marques, A.P., et al., Diffusion of anti-VEGF injections in the Portuguese National Health System. BMJ Open, 2015. 5(11): p. e009006.

16. Crewe, J., et al., Prevalence of blindness in Western Australia: a population study using capture and recapture techniques. Br J Ophthalmol, 2012. 96(4): p. 478-81.

17. Sarvananthan, N., et al., The Prevalence of Nystagmus: The Leicestershire Nystagmus Survey. Investigative Ophthalmology \& Visual Science, 2009. 50(11): p. 5201-5206.

18. Bukhari, W., et al., Incidence and prevalence of NMOSD in Australia and New Zealand. J Neurol Neurosurg Psychiatry, 2017. 88(8): p. 632-638.

19. Crewe, J.M., et al., Prevalence of blindness in children. Br J Ophthalmol, 2012. 96(12): p. 1537-8. 
medRxiv preprint doi: https://doi.org/10.1101/2021.07.06.21260069; this version posted July 7, 2021. The copyright holder for this preprint

(which was not certified by peer review) is the author/funder, who has granted medRxiv a license to display the preprint in perpetuity.

All rights reserved. No reuse allowed without permission.

Page 13 of 24

20. Nielsen, L.S., L. Skov, and H. Jensen, Visual dysfunctions and ocular disorders in children with developmental delay. I. prevalence, diagnoses and aetiology of visual impairment. Acta Ophthalmol Scand, 2007. 85(2): p. 149-56.

21. Campbell, H., et al., A capture-recapture model to estimate prevalence of children born in Scotland with developmental eye defects. J Cancer Epidemiol Prev, 2002. 7(1): p. 21-8.

22. Hayward, L.M., et al., What is the prevalence of visual impairment in the general and diabetic populations: are there ethnic and gender differences? Diabet Med, 2002. 19(1): p. 27-34.

23. Rahi, J.S. and C. Dezateux, Measuring and interpreting the incidence of congenital ocular anomalies: lessons from a national study of congenital cataract in the UK. Invest Ophthalmol Vis Sci, 2001. 42(7): p. 1444-8.

24. Rahi, J.S. and C. Dezateux, Capture-recapture analysis of ascertainment by active surveillance in the British Congenital Cataract Study. Invest Ophthalmol Vis Sci, 1999. 40(1): p. 236-9.

25. Barry, R.J. and P.I. Murray, Unregistered visual impairment: is registration a failing system? The British Journal of Ophthalmology, 2005. 89(8): p. 995-998.

26. Mauschitz, M.M., et al., Epidemiologie hochgradiger Sehbehinderungen und Blindheit älterer Menschen in Deutschland. Der Ophthalmologe, 2019. 116(2): p. 201-212.

27. Islam, N.S., et al., Methodological issues in the collection, analysis, and reporting of granular data in Asian American populations: historical challenges and potential solutions. J Health Care Poor Underserved, 2010. 21(4): p. 1354-81.

28. Ramos, P.L., et al., A Review of Capture-recapture Methods and Its Possibilities in Ophthalmology and Vision Sciences. Ophthalmic Epidemiol, 2020. 27(4): p. 310-324.

29. Statistics Portugal. Census 2011. 2011; Available from: https://censos.ine.pt/xportal/xmain?xpid=CENSOS\&xpgid=censos2011 apresentacao

30. International Statistical Classification of Diseases and Related Health Problems 10th Revision (ICD-10)-WHO Version for 2016. H54: Visual impairment including blindness (binocular or monocular). 2016; Available from: https://icd.who.int/browse10/2010/en\#/H54

31. Diário da República, Decreto-Lei n. $^{\circ}$ 202/96, R. Portuguesa, Editor. 1996: Diário da República (https://dre.pt/pesquisa/-/search/226809/details/maximized).

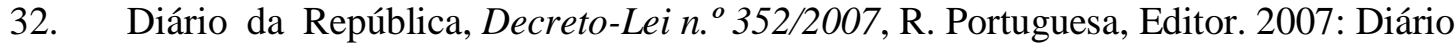
da República : https://dre.pt/application/file/a/629015.

33. Ramos, P.L., et al., Predicting participation of people with impaired vision in epidemiological studies. BMC Ophthalmol, 2018. 18(1): p. 236.

34. Lima Ramos, P., et al., Prevalence of Visual Impairment in the Municipality of Braga -Portugal using capture-recapture methods. Investigative Ophthalmology \& Visual Science, 2018. 59(9): p. 1069-1069.

35. Gordon, K., Crewe, J., Ramos, P.L, Macedo, A.F, \& Morgan, W. , Capturerecapture: a method for determining the prevalence of vision impaiment in the population. Clinical \& Experimental Ophthalmology, 2017. 45: p. 98-98.

36. Sudman, S., M.G. Sirken, and C.D. Cowan, Sampling rare and elusive populations. Science, 1988. 240(4855): p. 991-6.

37. Papoz, L., B. Balkau, and J. Lellouch, Case counting in epidemiology: limitations of methods based on multiple data sources. Int J Epidemiol, 1996. 25(3): p. 474-8.

38. Chao, A., et al., The applications of capture-recapture models to epidemiological data. Statistics in Medicine, 2001. 20(20): p. 3123-3157. 
medRxiv preprint doi: https://doi.org/10.1101/2021.07.06.21260069; this version posted July 7, 2021. The copyright holder for this preprint (which was not certified by peer review) is the author/funder, who has granted medRxiv a license to display the preprint in perpetuity. All rights reserved. No reuse allowed without permission.

Page 14 of 24

39. Rivest, L.-P. and S. Baillargeon, Package 'Rcapture' v1.4-3. CRAN.R-Project.org, 2019. https://CRAN.R-project.org/package=Rcapture

40. Baillargeon, S. and L.-P. Rivest, Rcapture: Loglinear Models for Capture-Recapture in R. Journal of Statistical Software, 2007. 19(5): p. 31.

41. Rius, A., et al., Visual Impairment and Blindness in Spanish Adults: Geographic Inequalities Are Not Explained by Age or Education. Ophthalmology, 2014. 121(1): p. 408-416.

42. Buch, H., et al., Prevalence and causes of visual impairment and blindness among 9980 Scandinavian adults: the Copenhagen City Eye Study. Ophthalmology, 2004. 111(1): p. 53-61.

43. Claessen, H., et al., Markedly decreasing incidence of cause-specific blindness in Saxony (Eastern Germany). Graefes Arch Clin Exp Ophthalmol, 2021. 259(5): p. 1089-1101.

44. Dutra Medeiros, M., et al., First Incidence and Progression Study for Diabetic Retinopathy in Portugal, the RETINODIAB Study: Evaluation of the Screening Program for Lisbon Region. Ophthalmology, 2015. 122(12): p. 2473-2481.

45. de Sousa-Uva, M., et al., Trends in diabetes incidence from 1992 to 2015 and projections for 2024: A Portuguese General Practitioner's Network study. Prim Care Diabetes, 2016. 10(5): p. 329-33.

46. Direção-Geral da Saúde, Norma n.016/2018, S.N.d. Saúde, Editor. 2018: https://normas.dgs.min-saude.pt/2018/09/13/rastreio-da-retinopatia-diabetica/.

47. Delcourt, C., et al., The Decreasing Prevalence of Nonrefractive Visual Impairment in Older Europeans: A Meta-analysis of Published and Unpublished Data. Ophthalmology, 2018. 125(8): p. 1149-1159.

48. Cachulo Mda, L., et al., Prevalence of Age-Related Macular Degeneration in Portugal: The Coimbra Eye Study - Report 1. Ophthalmologica, 2015. 233(3-4): p. 119-27.

49. Durnian, J.M., et al., Childhood sight impairment: a 10-year picture. Eye (Lond), 2010. 24(1): p. 112-7.

50. Rahi, J.S., Childhood blindness: a UK epidemiological perspective. Eye (Lond), 2007. 21(10): p. 1249-53.

51. Mitry, D., et al., Causes of certifications for severe sight impairment (blind) and sight impairment (partial sight) in children in England and Wales. Br J Ophthalmol, 2013. 97(11): p. 1431-6.

52. Lu, Q., et al., A population-based study of visual impairment among pre-school children in Beijing: the Beijing study of visual impairment in children. Am J Ophthalmol, 2009. 147(6): p. 1075-81.

53. Stevens, G.A., et al., Global prevalence of vision impairment and blindness: magnitude and temporal trends, 1990-2010. Ophthalmology, 2013. 120(12): p. 23772384.

54. Rius Ulldemolins, A., et al., Why are there gender inequalities in visual impairment? Eur J Public Health, 2019. 29(4): p. 661-666.

55. Kocur, I. and S. Resnikoff, Visual impairment and blindness in Europe and their prevention. The British journal of ophthalmology, 2002. 86(7): p. 716-722.

56. Cedrone, C., et al., Incidence of blindness and low vision in a sample population: The Priverno Eye Study, Italy. Ophthalmology, 2003. 110(3): p. 584-588.

57. Nowak, M.S. and J. Smigielski, The prevalence and causes of visual impairment and blindness among older adults in the city of Lodz, Poland. Medicine, 2015. 94(5): p. e505-e505. 
medRxiv preprint doi: https://doi.org/10.1101/2021.07.06.21260069; this version posted July 7, 2021. The copyright holder for this preprint (which was not certified by peer review) is the author/funder, who has granted medRxiv a license to display the preprint in perpetuity. All rights reserved. No reuse allowed without permission.

Page 15 of 24

58. Claessen, H., et al., Evidence for a considerable decrease in total and cause-specific incidences of blindness in Germany. Eur J Epidemiol, 2012. 27(7): p. 519-24.

59. Thomas, R.L., et al., Retrospective analysis of newly recorded certifications of visual impairment due to diabetic retinopathy in Wales during 2007-2015. BMJ Open, 2017. 7(7): p. e015024.

60. Scanlon, P.H., The contribution of the English NHS Diabetic Eye Screening Programme to reductions in diabetes-related blindness, comparisons within Europe, and future challenges. Acta Diabetol, 2021. 58(4): p. 521-530.

61. Maberley, D.A., et al., The prevalence of low vision and blindness in Canada. Eye (Lond), 2006. 20(3): p. 341-6.

62. McKibbin, M., T.M. Farragher, and D. Shickle, Monocular and binocular visual impairment in the UK Biobank study: prevalence, associations and diagnoses. BMJ open ophthalmology, 2018. 3(1): p. e000076-e000076.

63. Vaz de Sousa, A., Gestão de listas de espera para a cirurgia eletiva: o caso Português, in Relatório de Estágio, Faculdade de Ciências da Universidade de Coimbra. 2018.

64. Hernández-Moreno, L., et al., Cost-effectiveness of basic vision rehabilitation (The basic VRS-effect study): study protocol for a randomised controlled trial. Ophthalmic Physiol Opt, 2020. 40(3): p. 350-364. 
medRxiv preprint doi: https://doi.org/10.1101/2021.07.06.21260069; this version posted July 7, 2021. The copyright holder for this preprint (which was not certified by peer review) is the author/funder, who has granted medRxiv a license to display the preprint in perpetuity.

All rights reserved. No reuse allowed without permission.

Page 16 of 24

\section{Appendix}

Code used to implement the models according to Table 3

library(Rcapture)

$\mathrm{X}=$ matrix $(\mathrm{c}(1,0,0,118,1,1,0,38,1,0,1,39,0,1,1,59,1,1,1,13,0,1,0,768,0,0,1,4161)$,nrow=

$7, \mathrm{ncol}=4$, byrow $=$ TRUE)

Model1 =closedpCI.t $(X, \mathrm{dfreq}=$ TRUE, $\mathrm{mX}=\sim .+\mathrm{c} 1: \mathrm{c} 2+\mathrm{c} 2: \mathrm{c} 3)$

Model2=closedpCI.t $(X, d f r e q=T R U E, m X=\sim .+c 2: c 3)$

Model3=closedpCI.t $(X, d f r e q=T R U E, m X=\sim .+c 1: c 3+c 2: c 3)$

Model4=closedpCI.t(X,dfreq=TRUE,mX= .+c1:c2+c1:c3)

Model5=closedpCI.t $(X, d f r e q=T R U E, m X=\sim .+c 1: c 2)$

Model6=closedpCI.t $(\mathrm{X}, \mathrm{dfreq}=\mathrm{TRUE}, \mathrm{mX}=\sim .+\mathrm{c} 1: \mathrm{c} 3)$

Model $7=$ closedpCI.t $(X, d f r e q=T R U E, m X=\sim$.) 


\section{Tables and Figures}

Table 1: Prevalence of visual impairment in European countries. SVI= severe visual impairment; MVI=moderate visual impaiment; VA= visual acuity.

\begin{tabular}{|c|c|c|c|c|}
\hline Country & Year & Sample & VI definition & Prevalence \\
\hline Denmark & 2016 & $\begin{array}{l}3826 \text { participants aged } 20- \\
94 \text { years old from the } \\
\text { Danish General Suburban } \\
\text { Population Study }\end{array}$ & $\begin{array}{l}\text { The best corrected } \\
\text { visual acuity worse than } \\
20 / 40 \text { in the better- } \\
\text { seeing eye }\end{array}$ & $\begin{array}{l}0.4 \%(95 \% \mathrm{CI} \\
0.2-0.7)\end{array}$ \\
\hline Hungary & 2017 & $\begin{array}{l}105 \text { clusters of } 35 \text { people } \\
50 \text { years of age or older }\end{array}$ & $\begin{array}{c}\text { SVI-VA }<6 / 60-3 / 60 \\
\text { MVI- VA }<6 / 18-6 / 60\end{array}$ & $\begin{array}{l}\text { SVI, } 0.5 \%(95 \% \\
\quad \text { CI, 0.2-0.7) } \\
\text { MVI, 5.1\% (95\% } \\
\quad \text { CI, 4.3-5.9) }\end{array}$ \\
\hline France & 2005 & $\begin{array}{l}\text { Random stratified sample } \\
\text { of } 359010 \text { French citizens }\end{array}$ & $\begin{array}{l}\text { Self-reported visual } \\
\text { impairment }\end{array}$ & $1.95 \%$ \\
\hline Spain & 2014 & $\begin{array}{c}213626 \text { participants aged } \\
\geq 15 \text { years from a } 2008 \\
\text { Spanish Survey }\end{array}$ & $\begin{array}{c}\text { Distance and near } \\
\text { visual impairment } \\
\text { distinguished by } \\
\text { applying a } \\
\text { questionnaire }\end{array}$ & $\begin{array}{c}\text { Near visual } \\
\text { impairment - } \\
1.89 \% \\
\\
\text { Distance visual } \\
\text { impairment - } \\
1.89 \%\end{array}$ \\
\hline Germany & 2019 & $\begin{array}{l}\text { Population-based cohort } \\
\text { study in Germany } \\
\text { concerning } 14687 \text { adults } \\
\text { aged } 35 \text { to } 74\end{array}$ & $\begin{array}{l}\text { Acuity below } 0.3 \text { in the } \\
\text { better-seeing eye }\end{array}$ & $\begin{array}{l}0.37 \%(95 \% \mathrm{CI}, \\
0.28-0.49)\end{array}$ \\
\hline Iceland & 2008 & $\begin{array}{c}\text { Random sample of } 1045 \\
\text { citizens of Reikjavik aged } \\
50 \text { or more years }\end{array}$ & $\begin{array}{c}\text { Bilateral VI }- \text { best } \\
\text { corrected visual acuity } \\
\text { VA }<6 / 18 \text { or visual } \\
\text { field of }>\text { or }=5 \text { degrees } \\
\text { and }<10 \text { degrees } \\
\text { around the fixation } \\
\text { point in the better eye }\end{array}$ & $\begin{array}{l}0.96 \%(95 \% \mathrm{CI}, \\
0.37-1.55)\end{array}$ \\
\hline UK & 2002 & $\begin{array}{c}14600 \text { participants aged } 75 \\
\text { years and older }\end{array}$ & $\begin{array}{c}\text { Binocular visual acuity } \\
<6 / 18\end{array}$ & $\begin{array}{c}12.4 \%(95 \% \mathrm{CI}, \\
10.8-13.9)\end{array}$ \\
\hline
\end{tabular}


medRxiv preprint doi: https://doi.org/10.1101/2021.07.06.21260069; this version posted July 7, 2021. The copyright holder for this preprint (which was not certified by peer review) is the author/funder, who has granted medRxiv a license to display the preprint in perpetuity. All rights reserved. No reuse allowed without permission.

Page 18 of 24

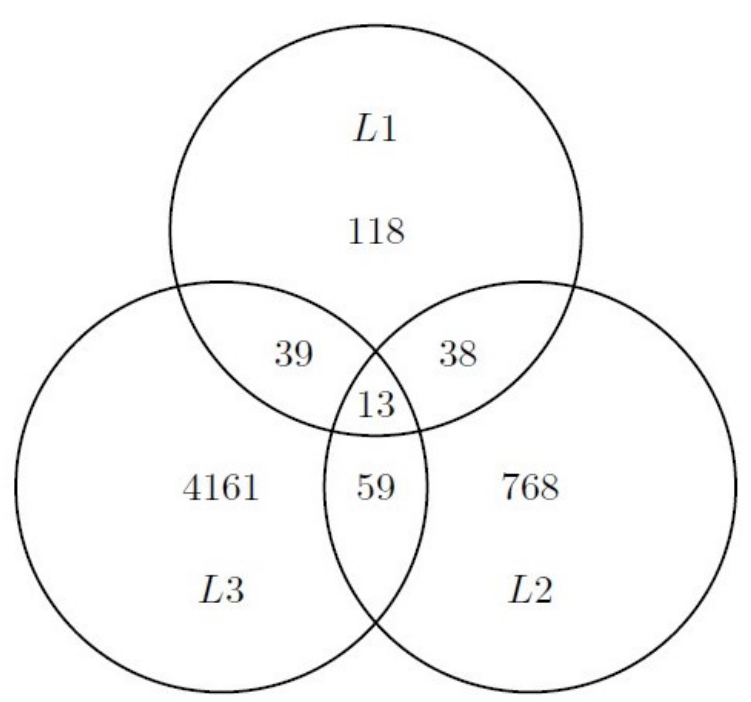

Figure 1: Venn diagram representing the overlap between the three lists. 
medRxiv preprint doi: https://doi.org/10.1101/2021.07.06.21260069; this version posted July 7, 2021. The copyright holder for this preprint (which was not certified by peer review) is the author/funder, who has granted medRxiv a license to display the preprint in perpetuity.

All rights reserved. No reuse allowed without permission.

Page 19 of 24

Table 2: Number of individuals presenting each possible capture history.

\begin{tabular}{|c|c|c|c|}
\hline L1 & L2 & L3 & Freq \\
\hline 1 & 1 & 1 & 13 \\
\hline 1 & 1 & 0 & 38 \\
\hline 1 & 0 & 1 & 39 \\
\hline 0 & 1 & 1 & 59 \\
\hline 1 & 0 & 0 & 118 \\
\hline 0 & 1 & 0 & 768 \\
\hline 0 & 0 & 1 & 4161 \\
\hline 0 & 0 & 0 & $x$ \\
\hline
\end{tabular}


medRxiv preprint doi: https://doi.org/10.1101/2021.07.06.21260069; this version posted July 7, 2021. The copyright holder for this preprint (which was not certified by peer review) is the author/funder, who has granted medRxiv a license to display the preprint in perpetuity.

All rights reserved. No reuse allowed without permission.

Page 20 of 24

Table 3: All possible log-linear models and resulting prevalence estimates. When we write, for example, $\mathrm{L} 1 \mathrm{~L} 2$ we are indicating that the model assumed dependence between $\mathrm{L1}$ and $\mathrm{L2}$. $\mathrm{N}$ - and $\mathrm{N}+$ represent lower and upper estimates of $\mathrm{N}$ according to a $95 \%$ confidence interval. $\mathrm{P}$-values test the hypothesis of the model fitting well (a value above 0.05 is indicative that the difference between the model predictions and the data is not statistically significant) the data and the Akaike's Information Criteria (AIC) is a criterion to choose between models by considering a balance between the number of fitted parameters and the maximum likelihood. Lower AIC values indicate better fitting of the data by the model.

\begin{tabular}{|c|c|c|c|c|c|c|}
\hline List Dependence & $\mathbf{N}$ & $\mathbf{N}-$ & $\mathbf{N}+$ & Prevalence & AIC & $\begin{array}{c}\text { P-value } \\
\text { goodness of } \\
\text { fit test) }\end{array}$ \\
\hline L1L2 L2L3 & 17754 & 14017 & 23467 & $0.60 \%(95 \%$ CI, $0.47-0.79)$ & 74.28 & $<0.001$ \\
\hline L2L3 & 11781 & 10200 & 13888 & $0.40 \%(95 \%$ CI, $0.34-0.47)$ & 142.10 & $<0.001$ \\
\hline L1L3 L2L3 & 7682 & 6931 & 8835 & $0.26 \%(95 \%$ CI, $0.23-0.30)$ & 109.86 & $<0.001$ \\
\hline L1L2 L1L3 & 59316 & 47038 & 76590 & $1.97 \%(95 \%$ CI, 1.56-2.54) & 58.59 & 0.92 \\
\hline L1L2 & 41042 & 34713 & 49157 & $1.38 \%(95 \%$ CI, $1.17-1.65)$ & 105.25 & $<0.001$ \\
\hline L1L3 & 36608 & 30991 & 43820 & $1.23 \%(95 \%$ CI, $1.04-1.47)$ & 234.08 & $<0.001$ \\
\hline All independent & 29587 & 25833 & 34201 & $0.98 \%(95 \%$ CI, $0.86-1.14)$ & 252.58 & $<0.001$ \\
\hline
\end{tabular}


medRxiv preprint doi: https://doi.org/10.1101/2021.07.06.21260069; this version posted July 7, 2021. The copyright holder for this preprint (which was not certified by peer review) is the author/funder, who has granted medRxiv a license to display the preprint in perpetuity. All rights reserved. No reuse allowed without permission.

Page 21 of 24

Table 4: Age-specific prevalence. P-values test the hypothesis of the model fitting well (a value above 0.05 is indicative that the difference between the model predictions and the data is not statistically significant) the data and the Akaike's Information Criteria (AIC) is a criterion to choose between models by considering a balance between the number of fitted parameters and the maximum likelihood. Lower AIC values indicate better fitting of the data by the model.

\begin{tabular}{|c|c|c|c|}
\hline Age & Prevalence & AIC & P-value (goodness of fit test) \\
\hline$<25$ & $0.07 \%(95 \%$ CI, 0.045-0.13) & 22.37 & 0.94 \\
\hline $25-64$ & $0.64 \%(95 \%$ CI, 0.49-0.88) & 53.94 & 0.77 \\
\hline$>64$ & $3.27 \%(95 \%$ CI, 2.36-4.90) & 50.43 & 0.82 \\
\hline
\end{tabular}


medRxiv preprint doi: https://doi.org/10.1101/2021.07.06.21260069; this version posted July 7, 2021. The copyright holder for this preprint (which was not certified by peer review) is the author/funder, who has granted medRxiv a license to display the preprint in perpetuity. All rights reserved. No reuse allowed without permission.

Page 22 of 24

Table 5: Sex-specific prevalence. P-values test the hypothesis of the model fitting well (a value above 0.05 is indicative that the difference between the model predictions and the data is not statistically significant) the data and the Akaike's Information Criteria (AIC) is a criterion to choose between models by considering a balance between the number of fitted parameters and the maximum likelihood. Lower AIC values indicate better fitting of the data by the model.

\begin{tabular}{|c|c|c|c|}
\hline Sex & Prevalence & AIC & P-value (goodness of fit test) \\
\hline Male & $1.67 \%(95 \%$ CI, $1.32-2.19)$ & 28.85 & 1 \\
\hline Female & $2.20 \%(95 \%$ CI, $1.65-3.08)$ & 28.58 & 1 \\
\hline
\end{tabular}


medRxiv preprint doi: https://doi.org/10.1101/2021.07.06.21260069; this version posted July 7, 2021. The copyright holder for this preprint (which was not certified by peer review) is the author/funder, who has granted medRxiv a license to display the preprint in perpetuity.

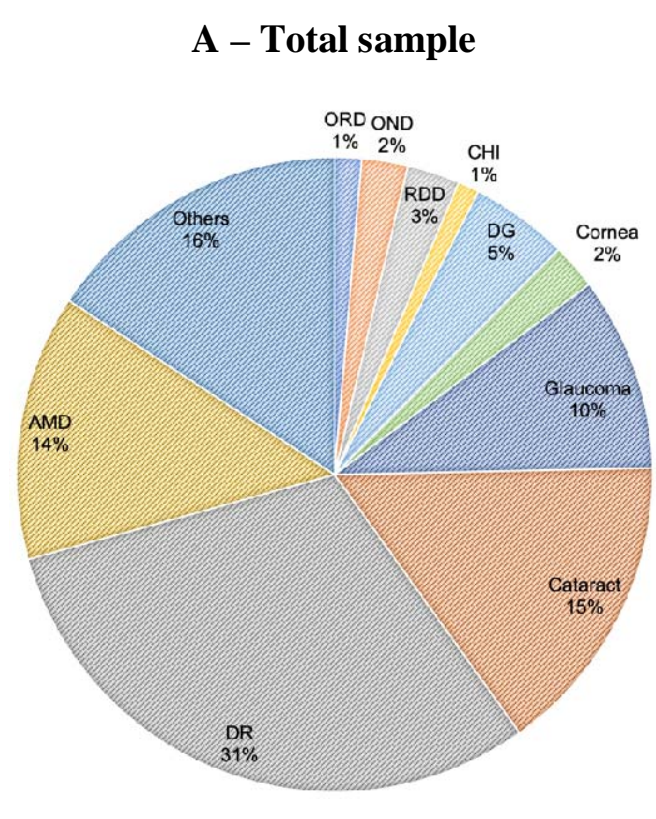

C - Age 25- 64 years

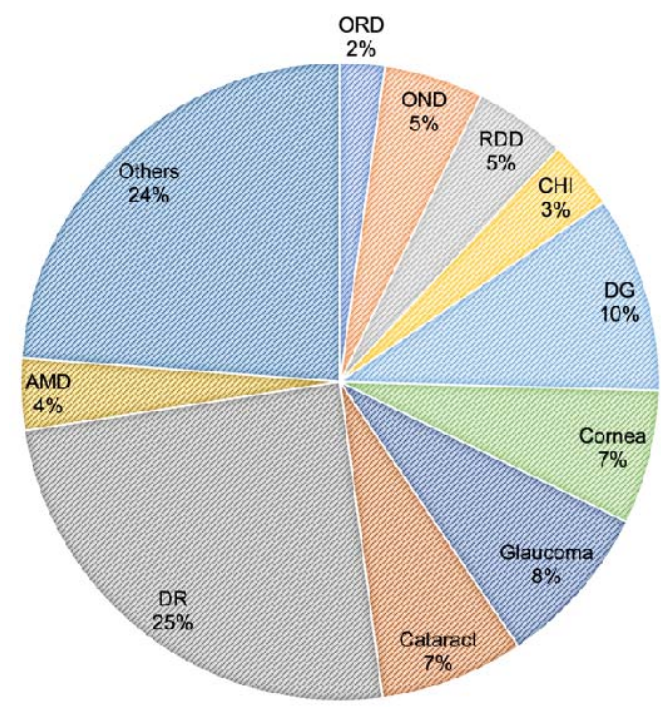

B - Age less than 25

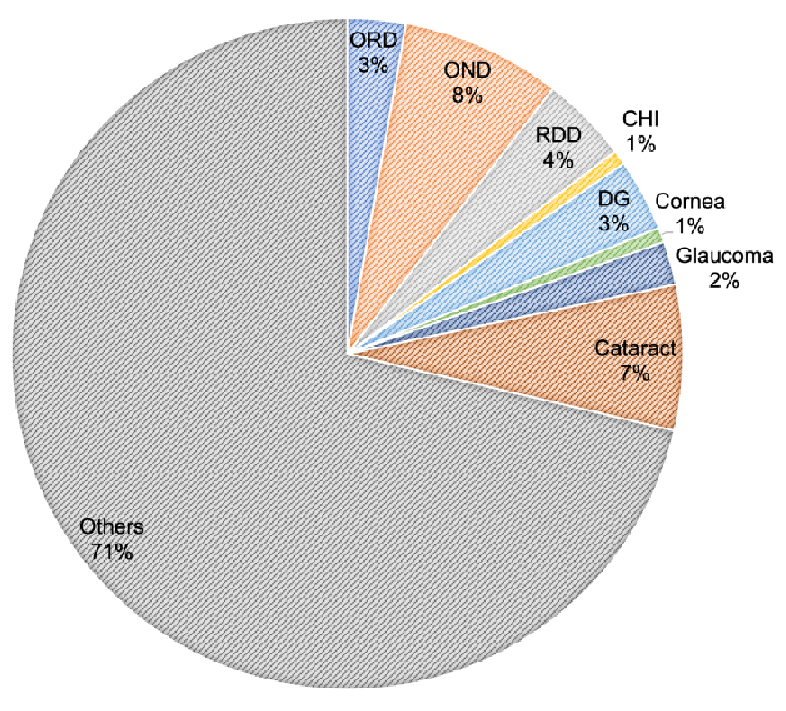

D - Age more than 64 years

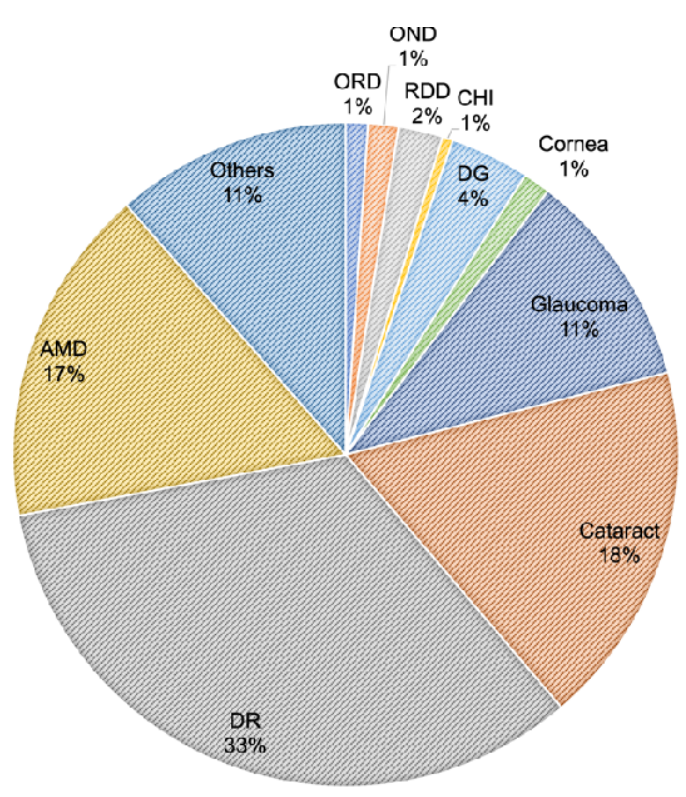

Figure 2: Distribution of causes of visual impairment. ORD = Other retinal disorders; OND = Optic nerve disorders DG = Disorders of the globe DR = Diabetic Retinopathy AMD = Age-related Macular Degeneration RDD = Retinal detachments and defects. The top 5 causes were: - for age less than 25 years, OND 8\% (95\% CI, 4 - 13), OND 7\% (95\% CI, 4 - 12), RDD 4\% (95\% CI, 2 - 9), DG 3\% (95\% CI, 1 - 8), ORD 3\% (95\% CI, 1 8); for age 25-64 years, DR 25\% (95\% CI, 22 - 28), DG $10 \%$ (95\% CI, 8 - 12), Glaucoma $8 \%(95 \%$ CI, 7 - 11), Cataract $7 \%(95 \%$ CI, 6 - 9), Cornea $7 \%$ (95\% CI, 6 - 9) and for age more than 64 years, DR 33\% (95\% CI, 32 - 35), Cataract 18\% (95\% CI, 17 - 19), AMD 17\% (95\% CI, 15 - 18), Glaucoma 11\% (95\% CI, 10 - 12), DG 4\% (95\% CI, 3 - 5). 
medRxiv preprint doi: https://doi.org/10.1101/2021.07.06.21260069; this version posted July 7, 2021. The copyright holder for this preprint (which was not certified by peer review) is the author/funder, who has granted medRxiv a license to display the preprint in perpetuity.

All rights reserved. No reuse allowed without permission.

Page 24 of 24

Table 6: Causes of visual impairment in 6 European countries, including Portugal.

\begin{tabular}{|c|c|c|c|c|c|}
\hline Our study & Denmark[42] & Scotland[14] & Italy[56] & Poland[57] & Germany[7] \\
\hline $\begin{array}{c}\text { Diabetic } \\
\text { retinopathy }\end{array}$ & Cataract & $\begin{array}{c}\text { Age related } \\
\text { macular } \\
\text { degeneration }\end{array}$ & Cataract & $\begin{array}{c}\text { Age related } \\
\text { macular } \\
\text { degeneration }\end{array}$ & $\begin{array}{c}\text { Age related } \\
\text { macular } \\
\text { degeneration }\end{array}$ \\
\hline Cataract & $\begin{array}{c}\text { Age related } \\
\text { macular } \\
\text { degeneration }\end{array}$ & Glaucoma & Myopia & Cataract & Glaucoma \\
\hline $\begin{array}{c}\text { Age related } \\
\text { macular } \\
\text { degeneration }\end{array}$ & $\begin{array}{c}\text { Diabetic } \\
\text { retinopathy }\end{array}$ & Cataract & $\begin{array}{c}\text { Age related } \\
\text { macular } \\
\text { degeneration }\end{array}$ & Amblyopia & $\begin{array}{c}\text { Diabetic } \\
\text { retinopathy }\end{array}$ \\
\hline $\begin{array}{c}\text { Glaucoma } \\
\text { Myopic }\end{array}$ & $\begin{array}{c}\text { Diabetic } \\
\text { retinopathy }\end{array}$ & $\begin{array}{c}\text { Diabetic } \\
\text { retinopathy }\end{array}$ & $\begin{array}{c}\text { Diabetic } \\
\text { retinopathy }\end{array}$ & $\begin{array}{c}\text { Corneal } \\
\text { Disease }\end{array}$ \\
\hline Cornea & $\begin{array}{c}\text { Other retinal } \\
\text { causes }\end{array}$ & Myopia & $\begin{array}{c}\text { not } \\
\text { available }\end{array}$ & Cornea & Genetic \\
illness
\end{tabular}

